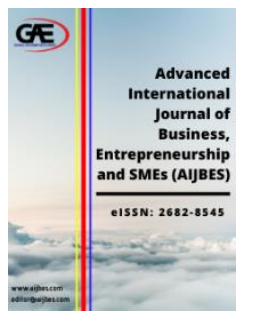

\author{
ADVANCED INTERNATIONAL JOURNAL OF \\ BUSINESS, ENTREPRENEURSHIP AND SMES \\ (AIJBES) \\ www.aijbes.com
}

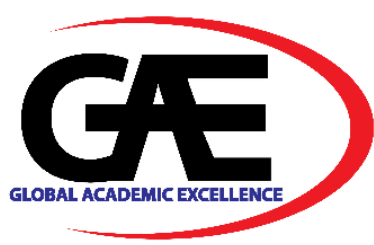

\title{
THE ISSUES OF NIGERIAN SMALL AND MEDIUM-SCALE ENTERPRISES IN THE GLOBAL SUPPLY OF HALAL PRODUCTS
}

\author{
Tajudeen Shehu Adebayo ${ }^{1 *}$, Jubril Salaudeen ${ }^{2}$ \\ 1 Abeokuta Business School, Crescent University, Ogun State, Nigeria \\ Email: tajudeen_shehu@yahoo.com \\ 2 Abeokuta Business School, Crescent University, Ogun State, Nigeria \\ Email: jubrilsalaudeen@gmail.com \\ Corresponding Author
}

\section{Article Info:}

Article history:

Received date: 18.03 .2021

Revised date: 21.03 .2021

Accepted date: 01.06.2021

Published date: 15.06.2021

\section{To cite this document:}

Adebayo, T. S., \& Salaudeen, J. (2021). The Issues of Nigerian Small and Medium-Scale Enterprises in The Global Supply Of Halal Products. Advanced International Journal of Business, Entrepreneurship and SMEs, 3 (8), 60-74.

DOI: $10.35631 /$ AIJBES.38004.

This work is licensed under CC BY 4.0

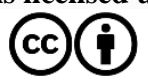

\begin{abstract}
:
The aim of this study is to explore the potentials of Nigerian Small and Medium-scale Enterprises (SMEs) in the global supply of Halal products. For this purpose, the study employed a desk research approach based on internet exploration, using specific keywords relating to the global Halal-centred industrial, investment, and export trade policy. The study found that Nigeria is yet to effectively key into the global Halal industry and market due to lack of functional Halal product certification management; under-researched nature of Halal export trade concepts; low investments into Halal business ventures; the novelty of interest-free business financing and low awareness of it among the SME owners. The study, therefore, recommends among other things, that government should incorporate the Halal business concept into the nation's industrial and export trade policy; establish a functional Halal Product Certification Department under the relevant government parastatals for industry and international trade; and promote awareness and support for Halal business financing to enhance the production capacity and export capability of the SMEs in the global supply of Halal products. The study also provided benchmark information for future empirical studies on the contribution of the Nigerian SME sector to job creation, export expansion, and foreign exchange earnings.
\end{abstract}

Keywords:

Halal Certification, Halal Market, Halal Products, Shari’ah 


\section{Introduction}

Nigeria is a promising emerging market with huge but yet untapped Halal export potentials for the Small and Medium-scale Enterprises (SMEs). The country has made tremendous wealth from the sale of its crude oil and natural gas which still account for $92.3 \%$ of the total exports. Available statistics shows that the contribution of the SMEs in the non-oil product exports (Halal and non-Halal) to total export, stood at 7.70\% (CBN, 2017, p. 230). This level is deplorably low given that the SME sector employs over $86.3 \%$ of the national workforce (National Survey of MSMEs, 2017). Some of the previous studies (Ajayi, 2016; Ogunjimi, Aderinto, \& Ogunro, 2015) have attributed the low SMEs' export performance to poor entrepreneurial orientation, instability in exchange rate of the Naira, inadequate export risk financing and poor government export support programmes, among others. A newly emerging evidence is however, beginning to show that Nigerian SME sector has been losing out a significant opportunity that exists in Halal industry and market, domestically and internationally (Mughal, 2017). Despite Nigeria's fifth position in the world by population of over 100 million Muslims (according to World Population Review, 2021), Halal business concept is yet to be fully incorporated into Nigerian industrial and export trade policy, while empirical research on Halal export orientation and how it can impact on Nigerian SMEs' performance in the global Halal market, still remains very low. This fact underscores the popular acceptance of globalization as a preferred way of trade and business practices among all economies (Muslim and non-Muslim countries alike) and the enormous emphasis being placed on safety, hygiene, reliability, ethicality and wholesomeness of Halal consumables (foods and non-food products).

Moreover, Halal has evolved from being a mark of religious identification to assurance and product safeguards from contamination by Halal accreditation frameworks, product certification processes and the entire management of Halal ecosystem (Research and Markets, 2021). The lack of functional Halal certification body with international recognition in Nigeria therefore, is an issue of great concern (Annabi \& Wada, 2016; Oyelakin \& Yusuf, 2018). Earlier on Mughal (2017) has described the absence of Halal certification body needed for Halal product standardization; and a robust regulatory framework for stability and global recognition in the evolving Nigerian Halal industry, as a drawback for the country's access to the global Halal export market. This has continued to limit the contribution of Halal industry to the nation's economic development. According to Ramlan (2021), there is a strong need to have in place, a functional Halal regulatory framework for Halal industry to work perfectly in Nigeria. The industry player asserted the need for the government to pay more serious attention to Halal industry and develop it as a viable agent of product exports to other countries. The Malaysian success in having a functional Halal Development Agency, HIDA, that has contributed immensely to the growth and development of Malaysian economy in terms of job creation, export expansion and foreign exchange earnings, provides a case study on the positive effects of Halal industry to the economy. Similarly, Sabrain (2021) emphasized the need for Nigeria to key into the strategic process of adding more values to Halal commodities and raw materials it exports to the global markets.

This process, the trade analyst argued, will not only showcase the competitive position of Nigeria's Halal market potentials but also, enhance the nation's non-oil export diversification process while boosting the SME sector's export performance as a key agro-industrial hub for African Halal market in the ongoing African Continental Free Trade Area (AfCFTA) agreement. 
The foregoing views thus, appear to suggest putting Nigeria in a vantage position as regards the nation's Halal potentials and export performance through its SMEs like Malaysia, Indonesia, Pakistan, Jordan, Egypt, the United Arab Emirate, and many of the non-Muslim dominated countries of Europe, Asia and the South America, which according to WHC (2021) are economies with certified global recognition and profitable engagements in Halal international markets.

The need to bridge the gaps as identified above and grow the Nigerian Halal industry with global trade opportunities for SMEs, represents the motivation for the present study which aims at exploring information on Halal product concept, its global market potentials, the relevance of the SME sector in the global Halal export market, as well as the significant factors affecting the industry in the global supply of Halal products. It is hoped that this research effort will provide benchmark information for future empirical studies on Halal business concept and the relevance of Nigerian SMEs in the global supply of Halal products.

\section{Literature Review}

\section{Halal Product Concept and Halal Market Potentials}

The term 'Halal products' is an Islamic concept which describes what is 'permissible' or 'lawful' for Muslims to consume or use. In Shari'ah, for a product or service to be permissible or licit for the Muslims, it must satisfy the laid down rules of Allah (Subhaanahu wa Ta'aala) as contained in the Quran and the authentic Ahaadith and Sunnah (i.e. sayings and practices) of Allah's Messenger, Muhammad (Salallahu alayhi wasalam). The opposite of the concept are things that are regarded as Haram or forbidden in Islam for Muslims. The Quran is emphatic on this, in the following verses:

[O you who believe! Eat of the good things that We have provided for you, and be grateful to Allah, if it is Him you worship. He has only forbidden you the Maitah (meat from dead animals), and blood, and flesh of swine, and that which is slaughtered as a sacrifice for others than Allah (or has been slaughtered for idols, on which Allah's name has not been mentioned while slaughtering.) But if one is forced by necessity without wilful disobedience nor transgressing due limits, then there is no sin on him. Truly, Allah is Oft-Forgiving, Most Merciful] (Al-Baqorah, Chapter 2 verse 172-173).

Similar instructions, prohibitions and reservations abound in the Quran and authentic Ahaadith. The purpose of Halal concept is thus, to define and regulate the domain of permissibility on foods, material usage and source of revenue as preconditions for consumables that are allowed for the Muslims. Accordingly, Muslim individuals and business organisations are also forbidden from engaging in, or deriving their revenues from interest-related businesses; alcohol, tobacco products; lottery business of any kind; pornographic business of any type; businesses connected with breeding of pigs, and or production or sales of animal blood, pork or their derivatives or by-products (Business Screen, Edbiz-Nasdaq Omx Sharia Index Family, 2014). The essence of these prohibitions is to satisfy Islamic guidelines and safeguard the Shari'ah requirements on purity, cleanliness and wholesomeness. Otherwise, the products are considered haram or unlawful to be consumed by Muslims (Khan \& Haleem, 2016). By implication therefore, Halal concept is a code of conduct and a perfect way of life for Muslims, as it defines the permissible limits in consumption of food types, usage of material things and 
Volume 3 Issue 8 (June 2021) PP. 60-74

sources of revenues, while it references Muslims' obedience to the commands of Allah, Almighty.

The potentials of the global Halal product market cover a wide range of products including: meat and poultry products from Shari'ah compliant slaughter houses, raw and processed food and beverages, ingredients and raw materials, pharmaceuticals, cosmetics and personal care products (GIFR, 2013). Halal market is however, not restricted to physical products alone. It includes also: Islamic banking and finance, takaful or Halal insurance services, healthcare, hospitality, education, logistic services and tourism. Each of the business categories as mentioned, possesses tremendous market potentials and foreign exchange earning opportunities for SMEs in the global Halal market. According to Halal Industry Development Corporation (HDC, 2016), the total worth of the global Halal market including Islamic financing, is currently estimated to be more than USD 4 trillion.

\section{Relevance of SMEs in the global supply of Halal products}

As the second fastest-growing religion in the world, Islam is well-acknowledged to be stimulating rapid increase in the global Halal product market that is worth USD trillions (Oyelakin \& Yusuf, 2018). This impactful role of Shari'ah requirements in Halal marketplace is also trendy in fashioning the consumption pattern and purchasing behaviour of many nonMuslim consumers who have found Halal products as clean, safe, healthy, more ethical and of high quality to consume across the globe (GIFR, 2013). In serving this highly promising and value-oriented market therefore, the role of the SMEs in promoting growth and attainments of the laudable objective of Halal product supply chain management, cannot be overemphasized. The importance of SMEs can easily be confirmed by the proliferation of this business type in global environment in food trading, eateries, sales of agricultural and lifestyle products which are the major classes of Halal product categories. The subsector therefore, has great potentials for creating copious employment in the area of health maintenance and wealth generation for the teaming population of Nigeria in Halal product chain management, if well harnessed. Besides, a well-performing export sector particularly in Halal product market for a country like Nigeria, can have multiplier effects that can enhance positive increase in the national income and reduce poverty prevalence and social costs of youth unemployment in the country. The Malaysian economy which is about the most prominent operator of functional Halal system has witnessed tremendous growth in the global Halal businesses. The country is continually aspiring to be a strong economic force and a regional pathway as a global Halal hub to Halal markets in the ASEAN (HDC, 2016). In its Shared Prosperity Vision (SPV) 2030, as well as the Halal Industry Master Plan, HIMP-2030, the Malaysian government has accorded a very high recognition to Halal industry, as being a strong promoter of Malaysian socio-economic growth and development. Malaysia thus, envisions improved Halal governance, capacity building programmes, and promotion of Halal industry, as issues of paramount importance. To that end, the $11^{\text {th }}$ Malaysian Plan for 2016-2020 was premised on specific national strategies and programmes designed to stimulate rapid and impactful results on invested capital and people of Malaysia (Eleventh Malaysia Plan, 2016 - 2020. Similarly, to consolidate the previous achievements made and ensure successful implementation of the comprehensive programmes envisaged in the HIMP-2030, the government's development blueprint in the $12^{\text {th }}$ Malaysian Plan, 2021-2025 and the $13^{\text {th }}$ Malaysian Plan, 2026-2030, is targeting poverty alleviation, socio-economic empowerment and drastic reduction in income disparity. The country according to Malay Mail (2021), is set to achieve the laudable objectives as noted by translating innovation and creativity to national wealth through dynamic SME sector for greater 
Volume 3 Issue 8 (June 2021) PP. 60-74 DOI 10.35631/AIJBES.38004

competitive advantage. Expectedly, the SMEs in Malaysia Halal industry are to benefit from the plans through enhanced automation and innovation system of production, accelerated human capital development programs, use of the latest technology and digitalization, improved Halal business environment, promotion of Islamic financing and quality investment policies with greater focus on high technology among other deliverables. Thus, while the role of Malaysia, a Muslim dominated country is well known in Halal product market in the ASEAN, Australia and Brazil have also, been recognized as the largest suppliers of Halal beef and poultry respectively to the Middle East! Likewise, while North Africa is pitched as the supply centre of olive oil, potatoes, vegetables \& fruits; the New Zealand is referred in supply of lamb and dairy products to the world Halal market. Indonesia on its part, is a stable source of global Halal supply of Chicken, Rice, Sugar, Soybean, Maize and Cassava; while Nigeria is acknowledged with a competitive position in supply of Yam, cassava, maize, vegetables and fruits to Halal market (see Table 1). Inclusively, sesame seeds, cashew nuts, ginger, fermented cocoa beans, crude palm kernel oil, soya beans, among other commodities totalling about $69.5 \%$ of agricultural exports with total value of $\mathrm{N} 210.2$ billion in 2018 , are becoming more noticeable in Nigerian export product profile, given the impressive results of government export diversification policy (PricewaterhouseCoopers, 2020). These agricultural products would increase the nomenclature and volume of Halal product supply by Nigerian SMEs in global Halal market.

Table 1: Global Supply of Halal Products

\begin{tabular}{lc}
\hline Country & Supply of Halal Products \\
\hline Malaysia* & Beef, Processed Food, Ingredients, Non-Food Products \\
Australia & Beef \& Dairy Products \\
Brazil & Poultry, Maize \& Animal Feed \\
Indonesia & Rice, Cassava \& Chicken, Maize, Sugar, Soybean \\
New Zealand & Lamb \& Dairy Products \\
North Africa & Olive Oil, Potatoes, Vegetables \& Fruits \\
Nigeria & Vegetables \& Fruits, Maize, Yams \& Cassava
\end{tabular}

Source: HDC, 2016; * The gateway to access Muslim market in ASEAN.

The growing interest in global Halal business as indicated in Table 2, has also, shown that China's domestic Halal market which is said to be worth USD 2.1 billion, is increasing by $10 \%$ annually, while as envisioned, Japan, Brunei, South Korea and Thailand will be well positioned to become Halal product destinations in foreseeable future (HDC, 2016).

Table 2: The Global Interest on Halal Product Market

\begin{tabular}{|c|c|}
\hline Countries & Interests \\
\hline United Arab Emirate & $\begin{array}{l}\text { Envisions becoming Centre of Islamic banking and } \\
\text { Halal businesses }\end{array}$ \\
\hline Thailand & $\begin{array}{l}\text { Largest producer of Halal processed food - visioning to } \\
\text { become the Kitchen of the World }\end{array}$ \\
\hline China & Domestic Halal market is increasing by $10 \%$ per annum \\
\hline South Korea & Visioning to become destination of Halal tourism \\
\hline Japan & $\begin{array}{l}\text { Halal, as key source of contributor to Japan's economy } \\
\text { by } 2025\end{array}$ \\
\hline
\end{tabular}


Source: Halal Industry Department Corporation (2016).

Therefore, with the enormous opportunities of Halal market in the Pacific Asia, the Middle East, Africa and the growing trend in Muslim community in China and Europe, the prospect of Halal marketplace holds very promising future outlook for exporting SMEs globally (HDC, 2016).The significant hurdle to cross for an aspiring economy like Nigeria with SME potentials in Halal products, is getting recognized internationally and accepted into the global Halal marketplace in order to exploit the new Islamic market trends and treasures. This status can only be attained through Halal awareness creation and trustworthy product certification and accreditation policy.

\section{Factors Affecting SMEs in The Global Supply of Halal Products}

Economic theory holds that supply of normal products as usual, is subject to conditions which may include among others: resource endowment, nature of production costs, entrepreneurial competence, production and technological capability, government policy, size of the market, as well as competitive ability of products' supplying agents. In addition, the supply of Shari'ahcompliant products to the global Halal market is also, subject to the following special conditions:

\section{Halal Certification and Qualification for Global Market Recognition/Acceptance}

This implies the need to satisfy the complex Shari'ah requirements in Halal products' supply chain including handling, storage, and transportation from the point of production, through transit points, and up to the final consumers. As far as Shari'ah of Islam is concerned, this is a major factor or condition of supply that must be satisfied in SMEs' global positioning and success in breaking the Halal market barriers internationally. This condition also, extends to include the use of current Halal certificates and proper use of Halal labelling or logo, as required by international Halal convention (MPPHM, 2014). Abdul, Ismail, Hashim, \& Johari (2009) have found a strong and significant association between religion and product certification, which tends to suggest that consumers' adherence to their religious teachings, has a great impact on their choice of products and services consumed. In the Muslim business world therefore, Halal certification process has become recognized as the most significant factor determining the success of SMEs in their access to, and performance in the global Halal export markets. Halal certification philosophy is more than just to satisfy the requirements on product quality or technical specifications. It is a religious and faith-induced affiliation that has been widely and globally embraced to cater for the interests of the Muslims and many non-Muslim alike in Halal product consumption. The process is however, not without its daunting challenges which range from possible falsification and corruption in products' value chain management to improper recognition of non-Muslim organizations in some countries, as Halal certifiers (Najjaar, T., 2020). The absence of uniformity in Halal practice and certification standards around the world is thus, one of the fundamental issues to the global Halal market and suppliers. To strengthen the Halal industry and safeguard the Halal market opportunities in Nigeria and Africa therefore, Sabrain, D. (2021) underscores traceability of Halal products value chain, standardization of certification process and safety of the entire Halal ecosystem from corruption, as the panacea for success and sustainability of the industry. The analyst called for effective partnership and collaboration between stakeholders from sciences and data analytics for Halal data security and integrity in order to ensure corruption-free certification 
Volume 3 Issue 8 (June 2021) PP. 60-74 DOI 10.35631/AIJBES.38004

process, enhanced trade practices and sanity in Africa's intra-continental Halal trading activities under the African Continental Free Trade Area (AfCFTA) agreement and beyond. In spite of the noted challenges however, Halal certification requirements on products and services still remains the key enabler for successful participation in the global Halal market (Global Halal Market Analysis, 2021).

\section{The Size Of Halal Consumer Market Globally}

Presently, there are over 1.9 billion Muslim population in the world and the figure keeps increasing by yearly average growth rate of $1.5 \%$ with a projection to reach 2.2 billion and account for $26.4 \%$ of the world total projected population of 8.3 billion by the year 2030 (Pew Research Centre, 2011). This shows that the Halal market is growing and expanding globally. Therefore, with the rising trend in Muslim population and the growing number of the nonMuslims who are ardent Halal product consumers, the global size of Halal market can be very large indeed. That also, implies a great potential attraction for Halal product exporting SMEs from around the globe. According to DinarStandard (2020/2021), the key drivers underpinning the growth in size of the global Halal market include among others, the growing commitment of the Muslims and the flourishing attraction of many non-Muslims to ethical values influencing consumption, as well as the increase in national strategies of many countries in favour of Halal products and service development. Currently, the most impressive outing of Halal market segment, are found in the Pacific Asia, the Middle East, North Africa, as well as Central and South America. These regions are the centers of Halal market places with greatest values and global Halal product supply impacts (Global Islamic Finance Report, 2013). The global supply of Halal product is however, not limited to the Muslim dominated countries alone. Business entrepreneurs and multinational corporations (MNC) in countries with Muslim minority like Brazil, the New Zealand, Thailand, Australia, United Kingdom and the USA among others, are often attracted by Islamic norms and guidelines on product hygiene and safety standards and have gainfully embraced Halal business concept in their business orientations. These countries are also known to be making heavy investments and significant strides in accessing the benefits of international Halal product market due to its positive contributions to their economies (DinarStandard (2020/2021).

\section{The Development of Shari'ah-Compliant Banking and Islamic Capital Markets}

Provision of business finance is crucial for survival of any business enterprise whether largescale or small-scale anywhere in the world. In a national survey of Nigerian MSMEs in 2017, access to finance was found to be greatest factor affecting the general supply capacity of the SMEs (SMEDAN \& NBS, 2017). This, according to the study was mostly due to high interest rates from conventional banks and their unwillingness to grant loan credits to SMEs due to poor collateral security capability of this form of businesses. Most importantly too, it is forbidden in Islam for Halal conforming business entity to source for business finances through interest-charging avenues like the conventional banks and interest-based capital markets (Edbiz-Nasdaq Omx Sharia Index, 2014). Therefore, creating an enabling environment of noninterest and accessible Halal source of funds in the banking sector, as well as in the capital markets, is an important factor in boosting the supply capacity and performance of SME sector in Halal products industry. Experts in the field believed very strongly that the Islamic interestfree banking and the stock market finance system are the best options for resolving the challenges currently facing the Nigerian economy (Adunola, 2017). Although while business financing through the non-interest banks and capital markets as Oluyombo (2005) observed, is relatively a novelty in Nigeria, the awareness on the benefits of Halal sources as an alternative 
Volume 3 Issue 8 (June 2021) PP. 60-74 DOI 10.35631/AIJBES.38004

business finance option is fast growing stronger both in the public and private sectors in Nigeria. This is because the interest free and profit-sharing sources of Halal financing has been found to be both profitable and morally upright. According to Investsmall (n.d), the Nigerian economy is making formidable progress in four major kinds of Halal investment namely: The Sukuk bonds, Halal Equity Funds, Ijarah, as well as Murabaha. The Sukuk Bond is a long term interest-free loan, that qualifies investors in it to be part owners of business assets and also, to regular payments with extra gains (when available) from the business profits. With Halal Equity Funds, investment is only allowed in businesses and services that are ethically and morally conforming. The Ijarah permits and encourages leasing owned assets (like buildings) to a party for a price, with additional income from the fixed rental charges over a fixed lease period; while Murabaha is a cost-plus financing option that seeks to operate more in trading activities by allowing joint agreement between buyers and sellers on the costs and markup of a specific asset at the beginning of a transaction. Of all the Halal investment types currently operating in Nigeria however, experts are of the opinion that the Sukuk bonds appears to be gaining more patronage in both public and the private sectors due to their high profit potentials and relative stability in returns.

Furthermore, Nigeria is the fifth largest Muslim population in the world (World Population Review, 2021). It is also, endowed with potentials to establish formidable governance for incorporation of Halal facilitation in its industrial and trade policy domestically, as well as to pursue export advocacy, networking and opportunities in cross border trade with OIC countries from Africa. As one of the new entrants to the top 15 leading countries in the Global Islamic Economy therefore, Nigeria is recognized globally for its fast-growing Islamic Finance sector among many of its evolving Halal business ventures.

Table 3: Indicator Score Breakdown for Top 15 Ranking Countries

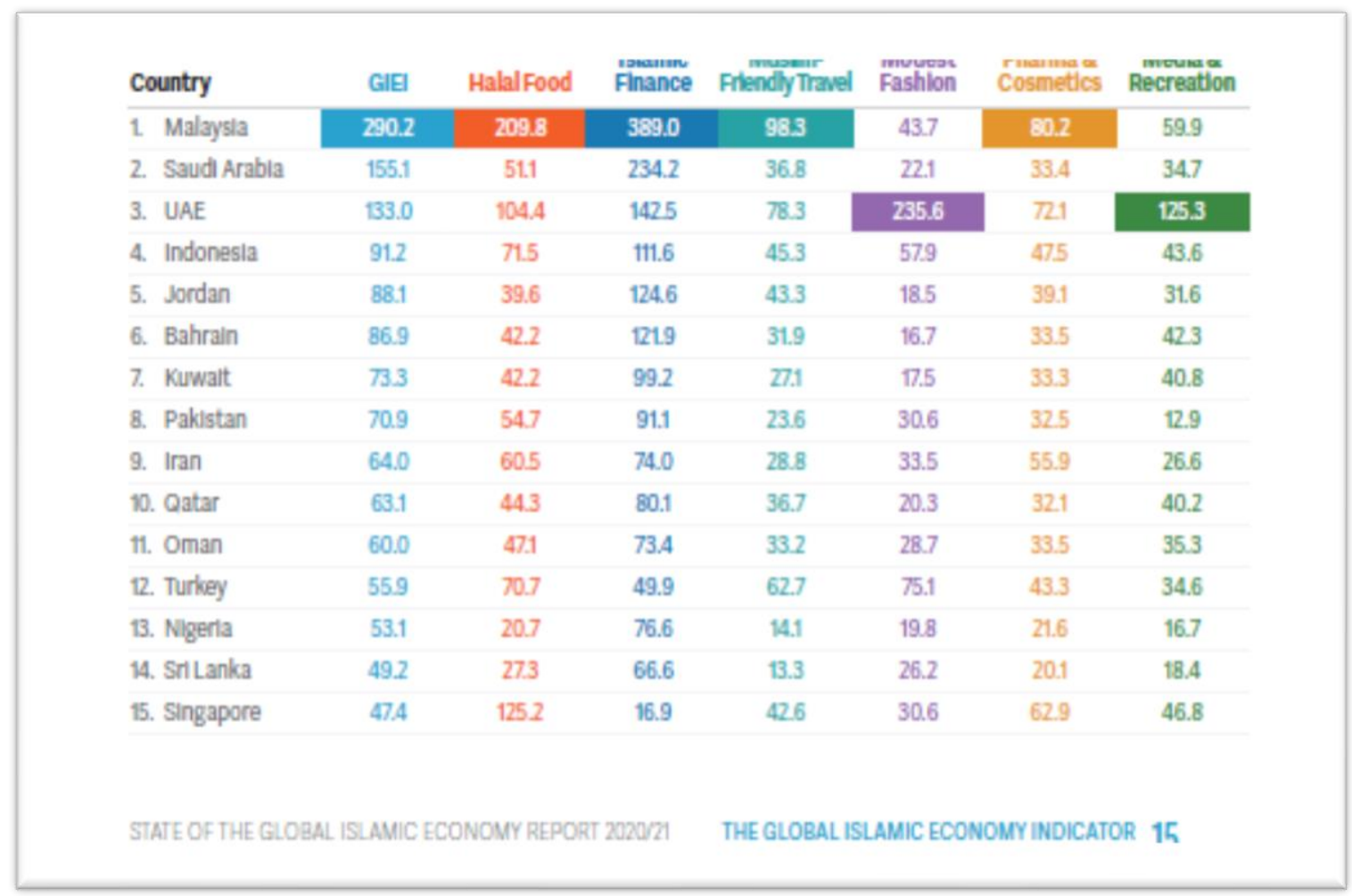

Source: DinarStandard (2020) on State of the Global Economy Report, 2020/2021 


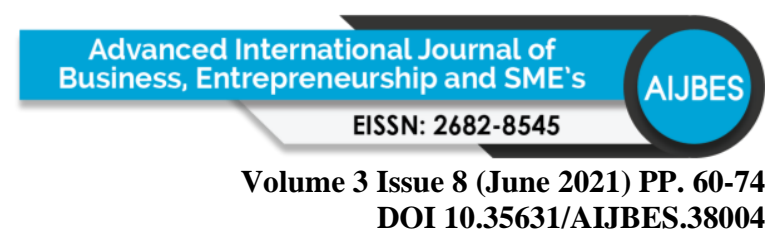

Thus, as shown in the Table 3 , while Malaysia continues to maintain its overall consecutive $8^{\text {th }}$ year lead in the rankings of the Global Islamic Economy Indicator (GIEI), followed by Saudi Arabia, UAE, Indonesia and other Halal-enabled countries, Nigeria fills the $13^{\text {th }}$ position out of the top 15 Halal economies with Sri-Lanka and Singapore in the $14^{\text {th }}$ and $15^{\text {th }}$ positions respectively (DinarStandard, 2020/2021).

\section{Research Methodology}

This study employed desk research approach in its methodology. The purpose is to explore the existing information on the global supply of Halal products based on countries with functional policy in Halal industry and market. In accessing the needed information for the study, we examined the relevant data sources on the topic through some of the available government, institution' and organization' websites including: www.worldhalalcouncil.com; www.halalfocus.net; www.globalhalaldatapool.com; www.worldpopulationreview.com; www.islamicpopulation.com; www.halal.gov.my; www.hdcglobal.com; www.son.gov.ng; www.nafdac.gov.ng; www.investsmall.co, etc.), as well as past research, using specific keywords relating to Halal industry and market on Muslim and non-Muslim dominated economies with Halal-enabled industrial, investment and export trade policy. The study particularly, anchored on the experience of Halal-practicing economies especially, Malaysia through its Halal Development Corporation Berhad (HDC) and Department of Islamic Development (Jabatan Kemajuan Islam Malaysia, JAKIM) which according to Soraji, et al. (2016), are commendable institutions in setting the global pace of development in Halal programmes, governance and for sourcing the relevant information on certification process on product integrity. This was done to gather available facts in presenting an overview of Halal product concept, certification issues, its market potentials and the relevance of the SMEs in the global supply of Halal products. This was also done to back-up the very scanty information available on Halal industry and market in Nigeria due to the dearth of research on the study area, and to identify the factors contributing to SMEs' access to, and successful performance in the global Halal products' market.

\section{Results and Discussions}

Halal product and service suppliers stand to lose out in the global Halal market due to lack of Halal certification agencies. According to Global Halal Data Pool (2021) however, this gap can be bridged, if and when the local Muslim communities and the government, established and effectively managed Halal Certification Bodies for products and services accreditation in their domain. Nigeria in its efforts towards export diversification from overdependence on crude oil and with her rich resource potentials in agriculture and human capital comprising of over 200 million Muslims and non-Muslim populations, most of whom are ardent consumers of Halal product and services, is currently not on the list of countries that are globally certified and recognized as prominent suppliers of Halal products and services (JAKIM, 2018; WHC, 2021). This mainly is due to lack of globally-recognised Halal market institutions and well-established frameworks for Halal product and service regulations, certification and accreditation processes in Nigeria (Mughal, 2017; Ramlan, 2021; Sabrain, 2021). Ostensibly, the country is yet to be integrated into the global Halal market despite the obvious relevance of its SME sector and the wide array of products and allied services in the agricultural sector with lots of Halal raw and semi-processed food materials, beverages, ingredients and animal feeds. Information from Standard Organization of Nigeria, SON (2017), shows that what obtains in Nigeria currently is a non-Halal product accreditation and certification system that is much overshadowed by the commonality of activities and guidelines on product standardization by the SON and the 


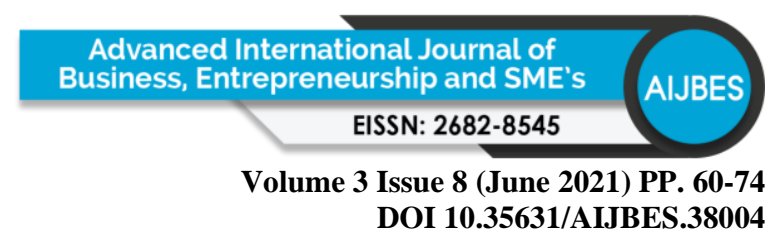

National Agency for Food and Drug Administration and Control (NAFDAC). The summary of the system as it is being currently practiced in Nigeria according to the Product Certification Directorate of the Standard Organization of Nigeria include:

- The mandatory conformity assessment programme (MANCAP): - which safeguards the conformity of made-in-Nigeria products to the relevant Nigerian Industrial Standards (NIS) and issuance of MANCAP certificate and logo on products before been allowed to be offered for sale domestically or internationally.

- Voluntary product certification scheme (NIS Mark of Quality): - which is the scheme for rewarding companies for excellence in products' compliance to Nigeria Industrial Standards (NIS) with the license to exhibit NIS Mark of Quality on the product concerned for special marketing advantages.

- The Nigerian quality award scheme (NQA): - is the scheme for rewarding made-in-Nigeria products for exceptional performance in conforming to specific criteria and key performance indicators as set by the SON's governing council.

- Product-type certification for exports: - refers to the issuance of certificate of conformance or documents indicating the compliance of companies to established standards by SON in order to facilitate export trade.

Thus, given the above situation, the aspiration of Nigeria to rank first in Halal market in Africa cannot be realized without a viable operation of a strong and sound Halal value chain system that can ensure the supply of globally acceptable ethical and wholesome products and services and enable Nigerian SME sector to compete fairly well for opportunities in the global Halal market (Sabrain D., 2021). This also, explains why the SME sector is losing out some key business opportunities including: the underserved domestic market of over 200 million Muslim and non-Muslim consumers of Halal products and services; the immense opportunity of becoming one of the global suppliers of Halal products and services in Africa and tapping profitably from the overall benefits of Islamic banking, insurance, global Halal certification and a huge share from the global Halal market, the estimated size of which is over 4 trillion US dollars (HDC, 2016; Mughal, 2017; Ramlan, 2021; Sabrain, 2021). To change the present scenario in favour of Nigeria, the case of Malaysian Halal industry playing pivotal role in deepening the economic contribution of the country's Halal sector through its governmentbacked Halal Development Corporation Berhad (HDC's) and the Malaysian Islamic Development department (JAKIM), presents a viable option available to Nigeria. Accordingly, while the HDC is responsible for Malaysia's integrated and comprehensive Halal guidelines and infrastructure on various business strategies that are directed at boosting the industrial and export trade performance indices in the economy, JAKIM provides the regulatory framework and certification processes for products and services in Malaysian Halal ecosystem. The two institutions (HDC and JAKIM) thus, work together with other Halal development stakeholders to ensure that Halal industry in Malaysia contribute significantly to the socio-economic development in Malaysian economy. Today, Malaysia is a leading Halal hub in the global arena with annual export value of over US\$10 billion that accounts for 4\% of the country's total exports. Nigeria thus, stands to actualize its dream of becoming a force to reckon with as a leading hub for Halal product exports in Africa, if the country can emulate the case of Malaysia and other similar 'Halal-enabled' economies like Indonesia, UAE, Saudi Arabia, Australia, Greece, Cyprus, Denmark, Malawi, Philippines, Italy, Cote D'ivoire, Hong Kong, South Africa, Canada, United Kingdom and the USA, by establishing and operating such Halal institutions and frameworks in its industrial and export trade development policy. These economies according to WHC (2021), operate functional Halal certification policies and 
Volume 3 Issue 8 (June 2021) PP. 60-74

DOI 10.35631/AIJBES.38004

authorities with global Halal recognition and are thus, prominent members in the committee of supplier nations of Halal products to international markets.

Another issue of relevance to the development of Halal industry and market in Nigeria is business financing. While Halal financing (Islamic Compliant Banking and Capital Market) system is still at evolving stage in Nigeria, its prospects and opportunities for the SMEs appear to be very great. Some of the activities and developments in the sector according to Financial Inclusion Newsletter (2020) of the Central Bank of Nigeria (CBN) include:

- the admission of Nigerian Securities and Exchange Commission (SEC) into the Membership of Islamic Financial Services Board (IFSB) on the 4th of June 2020;

- the flag-off of the Central bank of Nigeria, CBN's Intervention Programmes for the SMEs based on the New Non-Interest Finance Scheme;

- the Federal Government's readiness to advance the regulatory framework for integration of Islamic interest-free windows in all its intervention programmes for alleviating the effects of COVID-19 pandemic on Nigerian SMEs;

- the Islamic Development Bank's (IsDB's) US\$1.5bn Sukuk bonds for business sustainability and amelioration of the effects of COVID-19 Pandemic in the bank's 57 member countries. With a capital subscription of US\$3.9 billion (or 7.66\%) of the bank's total capital, Nigeria is a prominent member of IsDB and the OIC;

- the IsDB's assistance of providing insurance cover for Nigeria's US\$1.2 in-kind loan from Brazil on Green Initiative;

- the IsDB's support of US\$1.13 billion lent to Nigerian Government to finance part of the US $\$ 5.5$ billion 2020 budget deficit;

- the Debt Management Office (DMO) raised Sukuk of N162.557 bn for Ministry of Works and Housing for construction and rehabilitation of 44 roads across the country;

- the Kano-based US\$95 million Agro-Pastoral Development Project created by joint support from IsDB and Life and Livelihood's fund to boost and augment the State's agricultural productivity and competitiveness drive;

- the fast developing activities of non-interest finance operations by Jaiz Bank Plc; the United Capital "Sukuk Fund" for advancement of the non-interest finance market in Nigeria;

- the IsDB's supports to Microfinance banks in promoting affordable loans to farmers and small business owners across Nigeria

- and also, hosting of international Halal Expo, the first of which was organised in June 2020 by Abuja Chamber of Commerce and Industries (ACCI) in collaboration with Abuja Trade Centre; and attracted over 200 exhibitors and 50,000 visitors from various Halal enabled economies like Malaysia, Indonesia, Turkey, Saudi Arabia, etc. (Halal Expo Nigeria, 2020).

Consequently, the laudable events as described above, are all directed at closing the financial inclusion gaps in Islamic finance sector, stimulate the growth of Halal economy and impact positively on supply capacity of Nigerian SMEs in the global Halal market. With increasing trend in such events and processes therefore, Nigeria's Halal industry and its value chain can be boosted and grow to contribute positively to job and income creation, increase in exports and foreign exchange earnings. 


\section{Conclusion and Recommendations}

This paper has highlighted proven evidences to show the business opportunities for SME sector in Nigeria and the Sub-Saharan African countries, in their effective response to the growing global Halal market demands, given the enormous export potentials it offers. As a conclusion therefore, the lack of Halal certification agencies and regulatory authorities in Nigeria, has been found to be a great barrier to SMEs' access to the global Halal marketing opportunities (Ramlan, 2021; Sabrain, 2021; Mughal, 2017). This fact is corroborated by the finding of NBS \& SMEDAN (2017) in its survey study of the MSMEs which revealed that lack of access to international markets is one of the major obstacles to SMEs' export performance in Nigeria.

To improve on the current situation with Halal industry, Nigerian government as a matter of urgency needs to:

- incorporate Halal business concepts into the nation's industrial and export trade policy as found in Malaysia and other Halal-enabled economies;

- improve on Halal governance and increase Halal awareness on economic benefits inherent in Halal industry and markets while promoting Halal facilitation and capacity building;

- upgrade government incentive supports for certified exporting SMEs in Halal industry; and,

- close the financial inclusion gap in Nigeria by creating an effective regulatory framework for the development of more inclusive and socially driven system that integrates Islamic interest-free windows as a business finance option for the growth of the SMEs in Nigeria.

The above recommended steps when taken, will enhance the hub to hub links that will open up the cross-border Halal trade between Nigeria and other nations through the functional engagements of the SMEs in the global supply of Halal products to Muslims and non-Muslim consumers all over the world.

Furthermore, since it is obvious that the act establishing the current product accreditation and export certification in Nigeria, does not guarantee the requirements of Islamic shari'ah in Halal products and services consumed by the Muslims locally and internationally, a functional Halal Product Accreditation \& Certification Department (HPACD), is recommended for Nigeria. The proposed Halal authority will operate as a departmental unit under the existing Product Certification Directorate of the Standard Organization of Nigeria (SON) with the supervisory role of the National Agency for Food and Drug Administration and Control (NAFDAC), as well as other related institutions as may be considered necessary. The agency as envisaged, will be responsible for formulating and implementing policies regarding Shari'ah-based product certification processes for local consumption and for exports; and it will be managed by professionals in Islamic shari'ah on business and trading activities. The Nigerian Supreme Council for Islamic Affairs (NSCIA) will coordinate the selection and composition of the shari'ah professionals to direct the affairs of the new department, while the body when constituted will also, oversee the shari'ah compliance of any product or service to be tagged with Halal logo, as well as the overall Halal products' integrity in Nigeria.

And very importantly too, the Federal government will have to put in place, an effective sensitization programme against the religious bigotry of those who may want to perceive adoption of Halal business practices in Nigerian industrial and export trade policy as a plot by government to Islamize the country. This point is important in Nigeria especially, when we consider the judicial rancour that was staged by some people who were intolerant of shari'ah concept when Jaiz Islamic Bank PLC was first accredited to operate as an Islamic Bank by the 
Volume 3 Issue 8 (June 2021) PP. 60-74 DOI 10.35631/AIJBES.38004

Central Bank of Nigeria in 2015. The mischievous brouhaha and hullabaloo instigated by some individuals and religious groups, when Nigeria joined the Organization of Islamic Cooperation (OIC) in 1986, is also on record.

Finally, the SME stakeholders will also, need to enhance the sector's Halal product potentials and supply capacity by taking strategic investment actions on innovation and creativity that will ensure maximum benefits from the global opportunities existing in Halal industry and market domestically and internationally.

\section{Study Limitations and Contributions to Knowledge}

It is important to note that this study is limited both in scope and methods as it only provides benchmark information on the development of Halal business concept and the product supply to the global Halal market in relation to Nigerian business environment and export trade policy on Small and Medium Enterprises (SMEs). The implied benefits of the study are however, sure to stimulate interests in future empirical investigations on Halal product concepts; development of Halal product certification processes; Halal business environment, financing and capital market development for the growth of the small and medium-scale business enterprises in Nigeria. These will enhance increased contributions to job creation, income and foreign exchange earnings in Nigeria and countries with similar Halal products and service potentials in the sub-Saharan Africa.

\section{References}

Adunola, S. (2017). Nigeria: How Islamic Finance can stimulate economic recovery. Retrieved from: http:www.guardian.ng/features/how-islamic-finance-can-stimulateeconomic-recovery/

Ajayi, B. (2016). The Impact of Entrepreneurial Orientation and Networking Capabilities on the Export Performance of Nigerian Agricultural SMEs. Journal of Entrepreneurship and Innovation in Emerging Economies, 2(1) 1-23, 2016. DOI: 10.1177/2393957515619720. Pdf

Annabi, C., \& Wada, S. (2016). Halal Pharmaceutical Industry in Nigeria: A bitter pill to swallow. Journal of Emerging Economies and Islamic Research, 4(2). Pdf. Retrieved from: https://www.researchgate.net/publication/313350112_Halal_ Pharmaceutical_ Industry_in_Nigeria_A_bitter_pill_to_swallow/download

Central Bank of Nigeria, CBN (2017). Central Bank of Nigeria Annual Report-2017. Retrieved from:https://www.cbn.gov.ng/Out/2018/RSD/CBN\%202017\%20ANNUAL \%20REPORT_WEB.pdf (assessed 03/02/2019)

Central Bank of Nigeria, CBN (2020). Financial Inclusion Newsletter (2020). A Quarterly Publication of the Financial Inclusion Secretariat. Volume 5, Issue 4, December 2020. Retrieved from: http://www.cbn.gov.ng/FinInc/FinIncNewsletter.asp

DinarStandard (2020). State of the Global Islamic Report 2020/2021. Thriving in Uncertainty. Retrieved from: http: //www.salaamgateway.com

Eleventh Malaysia Plan, 2016-2020: Anchoring Growth on People. pdf

Global Halal Market Analysis (2021). Top Countries Data Industry Price Trend, Size Estimation, Industry Outlook, Business Growth, Report Latest Research, Business Analysis and Forecast Analysis Research | With Covid 19 Analysis. Retrieved from: https://www.ktvn.com/story/43330930/global-halal-market-analysis-2021-with-topcountries-data-industry-price-trend-size-estimation-industry-outlook-business-growthreport-latest (accessed on 20th May, 2021) 
Volume 3 Issue 8 (June 2021) PP. 60-74 DOI 10.35631/AIJBES.38004

Halal Expo Nigeria (2020). Fair Festival Conference. 8th -10th June 2020. Abuja Trade \& Convention Center. Retrieved from: https://islamicmarkets.com/events/halal-exponigeria-2020

HIMP (2030). Halal Industry Master Plan, 2030. Prominent, Visible and Globalized Halal Malaysia.

HDC (2016). Halal Industry the New Potential Market. Halal Industry Development Corporation,

29thSeptember2016.Pdf.Retrievedfrom:https://www.lscm.hk/sites/summi

t2016/files/file/Presentation/08\%20-

JAKIM (2018). The Recognized Foreign Halal Certification Bodies \& Authorities. Jabatan Kemajuan Islam Malaysia, Department of Islamic Development Malaysia (as at 1st Available at: www.Halal.gov.my/ www.myihab.my, pdf June, 2018).

Khan, M. I. \& Haleem, A. (2016). Understanding "Halal" and "Halal Certification \& Accreditation System"- A Brief Review. Saudi Journal of Business and Management Studies. Vol-1, Iss-1(Feb-Apr, 2016):32-42. Pdf. Retrieved from: https://www.researchgate.net/publication/303459476_Understanding_Halal_and_Hala 1Certification_Accreditation_System-_A_Brief_Review/download

Malay Mail (2021). MP teases 12th Malaysia Plan priorities, says focus on battling poverty, empowering Bumiputera community and green economy Retrieved from: https://www.malaymail.com/news/malaysia/2021/03/01/pm-teases-12th-malaysiaplans-priorities-says-focus-on-battling-poverty-emp/1953785

MPPHM (2014). Manual Procedure for Malaysia Halal Certification (Third Revision) 2014. Pdf. Retrieved from: www.halal.gov.my/v4/images/pdf/MPPHM2014BI.pdf

Mughal M. Z., H. (2017). Nigeria, out of U.S. \$2.3 trillion markets for lack of Halal Certification Agency - Mughal, Daily Trust Newspaper interview (August 21, 2017). Retrieved from: https://allafrica.com/stories/201708210344.html\%20Jamie\%20Haniff \%20RAMLEE_Halal\%20Malaysia\%20\%20Hong\%20Kong\%20(23\%20Sep).pdf

Najjaar, T. (2020). Challenges of Halal Certification. 12th International Halal and Toyyibah Products Conference. Retrieved from: http://www.worldhalalcouncil.com/challengesof-halal-certification.html

Ogunjimi, O., Aderinto, E., \& Ogunro, T. (2015). An Empirical Analysis on the Relationship between Non-Oil Exports and Economic Growth in Nigeria. International Journal of Academic Research in Business and Social Sciences Dec 2015, Vol. 5, No. 12, DOI: 10.6007/IJARBSS/v5-i12/1931 URL: http://dx.doi.org/10.6007/IJARBSS/v5i12/1931

Oluyombo, O. O. (2005). Interest Free Banking in Nigeria: The Way Forward. The Journal of banking and finance, Vol. 7, No. 2, pp 37-47

Oyelakin, I. O. \& Yusuf, A. H. (2018). Prospects of Halal Products in Developing Countries: Comparison between Nigeria and Malaysia. International Journal of Business Society, 2(8) 44-53. Pdf. Retrieved from: https://www.ijobs.com/uploads/1/1/6/4/116416337/10.30566.ijo- $\quad$ bs.2018.285.pdf

Pew Research Center (2011). The Future of the Global Muslim Population. Retrieved from: https://www.pewforum.org/2011/01/27/the-future-of-the-global-muslim-population/

PricewaterhouseCoopers, PwC (2020). Unlocking Nigeria's Agricultural Exports. Retrieved from: https://www.exporthub.ng/blog/2020/08/06/report-unlocking-nigeriasagricultural-exports-pwc/

Ramlan Osman (2021): Nigeria Needs a Broader Regulatory Framework to Support Halal 
Industry. Halal Integrity, Halal Trade, Middle East \& Africa, Research. Retrieved from: https://halalfocus.net/nigeria-needs-a-broader-regulatory-framework-tosupport-halal-industry/ (accessed on 20th May, 2021)

Research and Markets (2021). \$1.9 Trillion Halal Food Market - Global Industry Trends,

Share, Size, Growth, Opportunity and Forecast to 2026. Retrieved from: https://www.businesswire.com/news/home/20210420005812/en/1.9-Trillion-HalalFood- Market---Global-Industry-Trends-Share-Size-Growth-Opportunity-andForecast-to-2026---ResearchAndMarkets.com

Sabrain D. (2021). Interview: Nigeria Needs to Develop its Halal Value Chain to Compete Globally. Retrieved from: https://halalfocus.net/interview-nigeria-needs-to-developits-halal-value-chain-to-compete-globally/

Sharia Family - Nasdaq Omx Global Indexes (2014). Sharia Overview.pdf. Retrieved from: https://indexes.nasdaqomx.com/docs/Sharia_FactSheet.pdf

Soraji, A., Awang, M., \& Mohd. Yusoff, A. (2016). Malaysia Halal Trust: Between Reality and Challenges. Proceedings of ADVED 2016 2nd International Conference on Advances in Education and Social Sciences.

SMEDAN \& NBS Survey (2017). National Survey of Micro, Small \& Medium Enterprises (MSMEs).

Standard Organization of Nigeria, SON (2017). Product Certification. Retrieved from: http:/www.son.gov.ng/son-product-certification.

World Halal Council, WHC (2021). List of Full Members. Retrieved from: https://www.worldhalalcouncil.com/members\#5

World Population Review (2021). Muslim Population by Country. Retrieved from: https://worldpopulationreview.com/country-rankings/muslim-population-by-country 